\title{
Wild Ungulate Herbivory of Willow on Two National Forest Allotments in Wyoming
}

\author{
Paul J. Meiman, ${ }^{1}$ Mark S. Thorne, ${ }^{2}$ Quentin D. Skinner, ${ }^{3}$ Michael A. Smith, ${ }^{3}$ and Jerrold L. Dodd
}

Authors are ${ }^{1}$ Assistant Professor, Forest, Rangeland and Watershed Stewardship Department, Colorado State University, Fort Collins, CO 80523, USA; ${ }^{2}$ State Range Extension Specialist, Human Nutrition, Food and Animal Science Department, University of Hawaii at Manoa, Honolulu, HI 96822, USA; ${ }^{3}$ Professors, Department of Renewable Resources, University of Wyoming, Laramie, WY 82071, USA; and ${ }^{4}$ Chair/Professor, Agricultural Department, Cameron University, Lawton, OK 73505, USA.

\begin{abstract}
Willows (Salix) are important riparian plants and often used to indicate riparian condition. Many herbivores feed on willows, but there is limited information about willow browsing by wildlife except in national parks. This study was conducted to estimate wild ungulate herbivory of willow on two US Forest Service allotments in northern Wyoming and to compare these values to published estimates for national parks. We also compared total annual and seasonal willow utilization by wildlife between sites dominated by willows of different heights. The effects of height category, site, and season on willow utilization were determined with a repeated measures analysis. Four permanent willow utilization transects were established at each of six study sites per allotment on two allotments, in communities supporting planeleaf (Salix planifolia Pursh), Wolf's (Salix wolfii Bebb), Drummond's (Salix drummondiana Barratt ex Hook.), or Eastwood's (Salix eastwoodiae Cock. ex A. Heller) willow. Twenty-five twigs were marked per transect (distributed across 6-12 plants/transect). Lengths of marked twigs were recorded on four dates to estimate willow utilization for winter/spring, summer, and late summer/fall periods. Total annual willow utilization on one allotment $(53 \%)$ was similar to published estimates for national parks $(P=0.0864)$, whereas utilization for the other allotment $(58 \%)$ was greater $(P=0.0421)$ than national parks. Seasonal patterns of willow utilization differed among sites within height categories $(P<0.001)$. Total annual willow utilization by wildlife also varied by site within height category $(P=0.0165)$ but was not greater for short $(43-56 \%)$ versus tall $(59-63 \%)$ willow communities. Wildlife browsing of willow in this study equaled, or exceeded, estimates for national parks, where concern has been expressed about willow community conditions. Generalizations about willow utilization for tall and short willow communities are problematic. Management decisions should be based on site-specific information as opposed to generalizations.
\end{abstract}

\begin{abstract}
Resumen
Los sauces (Salix) son plantas importantes de las aéreas ribereñas y a menudo se utilizan para indicar la condición de esas áreas. Varios herbívoros ramonean estos sauces incluyendo el ganado y la fauna silvestre, pero existe poca información en relación al ramoneo de esta especie por fauna silvestre con excepción de los parques nacionales. Este estudio se realizó para estimar el ramoneo de los sauces por la fauna silvestre en dos sitios de USFS pastoreado por ganado o caballos en el Noreste de Wyoming y comparar estos valores a las estimaciones publicadas para los parques nacionales. También se comparó la utilización total por año, así como la estacional por la fauna silvestre entre sitios dominados por sauces a diferentes alturas. Se hizo un análisis de medidas repetidas para determinar los efectos de las categorías de la altura, sitio y estación en la utilización de los sauces. Cuatro transectos permanentes para medir la utilización de los sauces se establecieron en cada uno de los seis sitios del estudio por sección en las dos áreas. Veinticinco ramas se marcaron a lo largo de cada transecto (distribuidas a través de 6-12 plantas/transecto). La longitud de las ramas marcadas se registró durante 4 épocas para estimar la utilización de los sauces durante los periodos de invierno/ primavera, verano, y finales de verano/otoño. La utilización total por año, en una de las áreas (53\%) fue similar a las estimadas en las publicaciones de los parques nacionales $(P=0.0864)$, mientras que para la otra área fue mayor $(P=0.0421)$ con un $(59 \%)$. En ambas áreas, los patrones estacionales de utilización del sauce fueron diferentes entre los sitios y entre las categorías de la altura. $(P<0.001)$. La utilización total anual del sauce por la fauna silvestre en ambos sitios presentó también una variación por sitio entre la categoría de altura $(P=0.0165)$, pero no fue mayor para las comunidades pequeñas de sauces $(43-56 \%)$ comparadas con las comunidades altas (59-63\%). El ramoneo por la fauna silvestre en este estudio fue similar, y quizá exceda las estimaciones para los parques nacionales donde se ha tenido preocupación por la condición de la comunidad de los sauces. La generalización acerca de la utilización de los sauces para las comunidades altas y pequeñas es problemática. Las decisiones más apropiadas y efectivas de manejo y conservación se deben basar en información más en sitio-especifico contrario a generalizaciones.
\end{abstract}

Key Words: browsing, herbivory, Salix, shrubs, ungulates

Research was funded in part by the Wyoming Water Resources Center, the Hyatt Ranch, the Pitchfork Ranch, the WesMar Grazing Management Trust Fund, the SRM Hyatt Trust, the Wyoming Agricultural Experiment Station, and the Dept of Renewable Resources, University of Wyoming.

At the time of the research, the senior author was research assistant, Dept of Rangeland Ecology and Watershed Management, University of Wyoming, Laramie, WY 82071, USA.

Correspondence: Paul J. Meiman, Dept of Forest, Rangeland and Watershed Stewardship, Colorado State University, Fort Collins, C0 80523, USA. Email: pmeiman@warnercnr.colostate.edu

Manuscript received 10 October 2008; manuscript accepted 25 June 2009.

\section{INTRODUCTION}

The importance of riparian ecosystems was captured effectively in a review by Kauffman and Krueger (1984) and has been reiterated many times (e.g., Schulz and Leininger 1990; Green and Kauffman 1995; Holland et al. 2005; Matney et al. 2005; Thorne et al. 2005). Because of their importance, the need to identify plants to indicate riparian zone condition has increased 
(Smith 1980; Kauffman and Krueger 1984), and willows (Salix) are often used in this manner (Martin 1978; Van Velson 1978; Platts 1981; Kauffman et al. 1983; Knopf 1985; Kovalchik and Elmore 1992). The size of willow plants and willow community structure have been used as the basis for decisions that alter livestock management (Myers 1987; Burton et al. 1992; Bighorn National Forest 1995; US Department of the Interior Bureau of Land Management 1993, 1994), and more generally for evaluations of natural resource management and conservation in national parks (Chadde and Kay 1991; Singer et al. 1998a, 1998b; Zeigenfuss et al. 2002).

Two important questions must be addressed before willows can be used effectively as indicators of riparian condition and the acceptability of livestock grazing management where both wild and domestic ungulates exist. First, what degree of willow herbivory can be expected by wild ungulates, and is it important to partition use between the two groups of ungulates? Second, although willow height can be suppressed by herbivory, is it safe to assume that short willows are an indicator of high levels of use?

Herbivory by large ungulates can affect willow growth and willow community structure (Schulz and Leininger 1990; Chadde and Kay 1991; Holland et al. 2005) and is sometimes viewed as a negative impact on riparian zone vegetation (Gaffney 1941; Gunderson 1968; Sedgewick and Knopf 1991; Green and Kauffman 1995; Singer et al. 1998b; Baker et al. 2005). Woody riparian vegetation can be impacted by both domestic (Roath and Krueger 1982; Rickard and Cushing 1982; Schulz and Leininger 1990; Green and Kauffman 1995) and wild ungulates (McMillan 1953; Harry 1957; Kufeld 1973; Chadde and Kay 1991; Singer et al. 1998b; Zeigenfuss et al. 2002; Baker et al. 2005).

An impressive amount of research has been conducted on willow herbivory by wildlife, but most has been conducted in national parks (Singer et al. 1994, 1998a, 1998b; Zeigenfuss et al. 2002; Schoenecker et al. 2004; Baker et al. 2005) and may be applicable only to those areas. The degree of willow herbivory by wild ungulates in national parks can be significant and is often treated as a situation unique to national parks (Singer et al. 1994; Kay 1997; Singer et al. 1998b; Baker et al. 2005). This may lead to the assumption that wildlife use of willow in other areas is less important. Other studies have focused on domestic livestock impacts on willows where wild ungulates could also be present, but provide little or no information about wildlife use (Roath and Krueger 1982; Kauffman et al. 1983; Platts and Nelson 1985; Myers 1989; Smith et al. 1992; Green and Kauffman 1995). Those studies attribute all browsing impacts or all willow utilization (if measured) to domestic livestock even though it is possible that willows were browsed by both groups of ungulates.

Winward (1985) notes that riparian plant communities have great potential to change in response to altered land management practices, but several studies report slow response of willow communities to alterations in livestock management (Roath and Krueger 1982; Szaro and Pase 1983; Conroy and Svejcar 1991; Shaw 1992). Assuming that wildlife had access to areas of interest in those studies, changes to livestock management would have altered an unknown portion of the total herbivory experienced by plants in the areas, and this may help explain the slow responses observed. Some studies have acknowledged this possibility (Shaw 1992), but many have not. Other studies have reported rapid and noticeable changes in riparian communities following livestock exclusion (Gunderson 1968; Dahlem 1978; Schultz and Leininger 1990). These changes have been attributed largely or entirely to exclusion of livestock. Although there is little doubt that domestic grazing had been removed, wildlife use patterns may have been affected.

Plant height is often used as an indicator of willow herbivory with an assumption that short, or height-suppressed, willows indicate heavy browsing pressure (Singer et al. 1994, 1998b; Zeigenfuss et al. 2002). Further, numerous studies have reported an increase in willow height after the reduction of herbivory (Brookshire et al. 2002; Schoenecker et al. 2004; Baker et al. 2005; Holland et al. 2005). Such findings have led to broad-scale objectives (explicit or implied) for increased willow height and livestock management recommendations believed necessary to achieve such objectives (Wyman et al. 2006; Bighorn National Forest 2007). This reasoning assumes that reduced aboveground herbivory will lead to increased plant size. Therefore, testing the basis of this assumption (that plant height can be used to estimate willow utilization) is important.

The study presented here was initiated, in part, because of concerns about willow height. Willow communities at several locations where our study was conducted were believed to be "height-suppressed" because of herbivory. Further, it was believed that livestock were the animals responsible for the herbivory leading to suppressed willow heights. At one location, local managers offered an elaborate explanation for an obvious difference in willow height between two adjacent areas. It was assumed that the human activity along a trail suppressed livestock herbivory in the area with tall willows, resulting in heavy livestock use and short willows in the adjacent area. Later it was determined that a difference in willow species composition was the reason for the difference in shrub height.

Our study was conducted to provide landscape-level information on seasonal patterns of willow herbivory by wild ungulates on two different livestock grazing allotments managed by the United States Forest Service (USFS) on two separate mountain ranges in northern Wyoming. Originally we planned to partition willow use between wild and domestic ungulates, but a last-minute decision resulted in no livestock use of one allotment, and there was limited livestock use on the other. The emphasis then shifted to quantifying willow herbivory by wild ungulates, but this required measuring willow utilization by cattle in the isolated situations where it occurred. The first objective was to estimate the percentage of available annual willow growth consumed by wildlife in a 12mo period on two USFS cattle and horse allotments in northern Wyoming and to compare these estimates to published estimates of willow utilization by wildlife in Yellowstone (YNP) and Rocky Mountain National Park (RMNP). Estimated willow utilization by wild ungulates in YNP and RMNP is $30-35 \%$ of current annual growth (Singer et al. 1998b; Zeigenfuss et al. 2002). We hypothesized that total annual willow utilization by wildlife in our study would not differ from published estimates and reinforce the importance of quantifying willow herbivory by wildlife in areas other than 
Table 1. Characteristics of willow utilization study sites on two United States Forest Service cattle and horse allotments in northern Wyoming, USA.

\begin{tabular}{llccl}
\hline Allotment & \multicolumn{1}{c}{ Site } & Height category & Elevation $(\mathrm{m})$ & \multicolumn{1}{c}{ Dominant willows } \\
\hline Greybull & Jack Creek & Tall & 2860 & $\begin{array}{l}\text { Salix drummondiana Barrat ex Hook } \\
\text { S. eastwoodiae Cock. ex Heller }\end{array}$ \\
Greybull & Kay Creek & & & S. planifolia Pursh var. monica (Bebb) Schneider \\
Greybull & Lower Haymaker & Short & 2985 & $\begin{array}{l}\text { S. drummondiana Barrat ex Hook } \\
\text { S. eastwoodiae Cock. ex Heller }\end{array}$ \\
Greybull & Tall & & 2660 & S. planifolia Pursh var. monica (Bebb) Schneider \\
Greybull & Upper Haymaker & Short & 2890 & S. wolfii Bebb \\
Greybull & Upper Jack Creek & Short & 2925 & S. eastwoodiae Cock. ex Heller \\
Paintrock Creek & Tall & & S. planifolia var. planifolia Pursh \\
Paintrock & Long Park Y & Tall & & S. drummondiana Barrat ex Hook \\
Paintrock & North Fork Paintrock & Tall & 2905 & S. eastwoodiae Cock. ex Heller \\
Paintrock & North High Park & Short & & S. drummondiana Barrat ex Hook \\
Paintrock & Poacher & Short & 2645 & Slanifolia Pursh var. monica (Bebb) Schneider \\
Paintrock & Upper Long Park & Short & 2940 & S. planifolia Pursh var. monica (Bebb) Schneider \\
\hline
\end{tabular}

national parks. The second objective was to determine if generalizations about willow utilization intensity should be based on willow height. We addressed this objective by comparing total annual and seasonal willow utilization by wild ungulates between sites dominated by willows of different heights on the same two allotments. We hypothesized that seasonal willow utilization by wild ungulates would differ between short and tall willow sites. More specifically, we expected winter and early spring utilization of short willow sites to be lower than that of tall willow sites, and no difference between tall and short willow sites in summer and early fall. Based on previous work and common management assumptions, we also hypothesized that total annual willow utilization would be higher for short willow sites than for tall willow sites.

\section{METHODS}

\section{Study Areas}

Two USFS grazing allotments in northern Wyoming were chosen as study sites for this project. Summer cattle grazing was permitted on both allotments, and wild, native ungulates had access to the study areas throughout the year.

The Greybull allotment (lat $44^{\circ} 02^{\prime} \mathrm{N}$, long $109^{\circ} 19^{\prime} \mathrm{W}$ ) on the Greybull District, Shoshone National Forest is located in the Absaroka Mountains approximately $40 \mathrm{~km}$ west of Meeteetse, Wyoming. This allotment has an area of 14769 ha divided into 12 management units determined largely by geographical barriers but also by water developments and some fence. One thousand and thirty-seven cow-calf pairs typically used the allotment between 10 July and 24 August; however, no cattle used this allotment during our study. Intensive, full-time herding and utilization monitoring are used to achieve desired animal distribution and utilization targets. The Paintrock allotment (lat $44^{\circ} 21^{\prime} \mathrm{N}$, long $107^{\circ} 21^{\prime} \mathrm{W}$ ) on the Paintrock District of the Bighorn National Forest is located approximately $100 \mathrm{~km}$ east of Meeteetse, Wyoming, in the Big Horn Mountains. This allotment has an area of 17371 ha divided into 11 management units by geographical barriers and fence. Permitted use on the allotment allowed for 1032 cow-calf pairs between 10 July and 22 September, and cattle were rotated as a single herd through management units based on utilization targets and monitoring. Horses are also permitted on both allotments, but to our knowledge, this has been limited to the horses used for herding cattle ( $<10$ head per allotment), and none of our study sites were located in horse pastures. Geology of the two mountain ranges differs (Heroy 1941; Dunrud 1962), but climate and vegetation are generally similar. Elevation across both allotments ranges from $2150 \mathrm{~m}$ to over $3700 \mathrm{~m}$. Annual precipitation ranges from $380 \mathrm{~mm}$ at lower elevations to $1020 \mathrm{~mm}$ in the higher elevations.

Ten different willow communities were identified on each allotment by Meiman (1996). Permanent willow utilization transects were established at six study sites on each allotment in the fall of 1994 (Table 1). Areas selected for utilization transects were representative of willow communities identified by Meiman (1996) in terms of species present and the range of utilization pressure observed. Three of the six sites on each allotment were established where the overall appearance of the willow community was short. Willows in these areas had uniform heights, and individual shrubs greater than $1 \mathrm{~m}$ tall were absent or uncommon. The other three sites on each allotment were established where the overall appearance of the willow community was much taller. Individual shrubs in these areas were commonly greater than $1 \mathrm{~m}$ tall, and shrub height was more variable among plants in the community. All sites were dominated by willows known to be browsed by large ungulates. Plant nomenclature follows Dorn (1992).

The Greybull sites ranged in elevation from 2645 to $2985 \mathrm{~m}$. Tall willow sites on this allotment included Jack Creek, Lower Haymaker, and Willow Creek. Short willow communities included Kay Creek, Upper Haymaker, and Upper Jack Creek.

The Paintrock sites were purposely located within approximately the same range of elevations as Greybull sites. Tall willow communities included North Fork, Long Park Y, and 
Willow Swamp. Short willow communities included North High, Upper Long Park, and Poacher.

Willow utilization for the Greybull allotment represents wildlife use only. Permittees and USFS personnel decided to rest this allotment from cattle grazing in the summer of 1995 because of a cool wet spring and a shortened growing season. Elk, moose, and deer were present on the Greybull allotment for much of the year, and the area is an important winter range for moose. Willow utilization data were recorded separately for wildlife and cattle on the Paintrock allotment. Cattle (600 cowcalf pairs) spent $2 \mathrm{~d}$ (14 to 15 August) in the North Fork and Willow Swamp sites during the summer period while being moved to a different pasture. The cow herd spent $18 \mathrm{~d}$ (17 August to 3 September) in North High, and $9 \mathrm{~d}$ (30 August to 7 September) in North Fork and Willow Swamp sites during the summer/fall period. Much of the Paintrock allotment is transitional range for elk moving between summer and winter ranges.

\section{Vegetation Measurements}

Four permanent transects (transect $=$ experimental unit) were randomly located at each of the 12 study sites (six sites on each allotment). A total of 25 individual twigs located on 6-12 plants along each transect were marked with colored wire in September 1994. Wire colors on each plant were unique and recorded to allow positive identification of twigs at every utilization reading. All marked twigs were within $2 \mathrm{~m}$ of the ground and within reach of large ungulates. Shrubs over $2 \mathrm{~m}$ tall were rare at our study sites, so marked twigs provided a reasonable estimate of utilization. Browsed twigs were not avoided, but unbrowsed twigs were abundant, so very few browsed twigs were marked. The length and browsing status of each twig were also recorded. Browsing status included browsed, unbrowsed, or stripped (obvious animal damage to bark and loss of leaves, but twig still attached to the plant). Twig length was measured from the growth scar to the base of the pseudoterminal bud on unbrowsed current year's growth and from the growth scar to the point of removal on browsed twigs. The total length of the twig and the amount of dead material (if present) were also noted. Only dead or damaged twig material that could be attributed to herbivory was considered utilization. A linear regression developed by Meiman (1996) suggested that twig length explained $90 \%$ of the variation in twig weight. Therefore, twig length removed by browsing provided a reliable index of utilization.

Twig length measurements were taken in September 1994, mid-July 1995, mid- to late August 1995, and October 1995 and allowed estimation of willow utilization for three periods (October 1994-mid-July 1995, winter/spring; mid-July-late August 1995, summer; late August-October 1995, summer/ fall). Additional measurements were taken immediately before and after cattle presence at a site to partition seasonal utilization into wildlife and livestock components. The utilization survey was conducted on twig material from two growing seasons. Twigs measured for the winter/spring period were produced in the 1994 growing season, and those measured in the summer and summer/fall periods were produced in the 1995 growing season. Additional twigs were marked as necessary each time twig lengths were measured to maintain 20-25 marked twigs on each transect throughout the study. Individual twig lengths along each transect were summed for each reading, and the change in total twig length for a transect in a period constituted one observation of utilization.

\section{Data Manipulations and Statistics}

The total length of marked twigs available to herbivores in each period was determined for each transect. Growth factors (Meiman 1996) were calculated for each site in each utilization period by determining the percentage increase in length of twigs that were unbrowsed for the entire period. The growth factor was then applied to twigs that were unbrowsed at the beginning of the period and browsed at the end of the period to determine twig length available in each period. The difference between twig length at the end of the period and the adjusted available twig length for that period constituted removal. Transect totals for twig length removed and available twig length in each period were determined and seasonal utilization was estimated using the equation

$$
U=\left(\left[L_{1}-L_{2}\right] \div L_{1}\right) \times 100,
$$

where

$$
\begin{aligned}
U & =\text { utilization (\%) } \\
L_{1} & =\text { available twig length for the period, and } \\
L_{2} & =\text { twig length at the end of a period. }
\end{aligned}
$$

The use of twig material from two growing seasons and remarking twigs results in the possibility that the sum of seasonal utilization estimates across three periods for a given site may exceed $100 \%$. Therefore, total annual willow utilization at each site was estimated using all twig material marked in the three periods resulting in values between $0 \%$ and $100 \%$.

Estimated willow utilization by wild ungulates in YNP and RMNP is $30-35 \%$ of current annual growth (Singer et al. 1998b; Zeigenfuss et al. 2002). For each allotment, one-sample $t$-tests $(n=6$ sites per allotment) were used to test the null hypotheses that total annual willow utilization equaled 30\% and $35 \%$. Seasonal willow utilization was analyzed with a three-factor nested design with repeated measures (season) (Engeman et al. 1986; Girden 1992). Sites were nested within height category. Analysis of variance was used to determine the effects of height category (tall or short), season, and site within height category on willow utilization. All possible interactions were tested. Total annual willow utilization of short versus tall willow sites was analyzed using a two-factor nested design. Analysis of variance was used to test the effects of height category and site nested within height category on total annual willow utilization for each allotment. Mean separations were based on protected least significant difference tests (Montgomery 1984) and an overall $\alpha$ of 0.05 . Analyses were conducted using SAS version 9.1 (SAS Institute 2003).

A snow storm in late October 1995 prevented sampling of the Kay Creek and Willow Creek sites on the Greybull allotment for the summer/fall period and resulted in missing values for those sites. There were no missing values in the Paintrock analyses. 


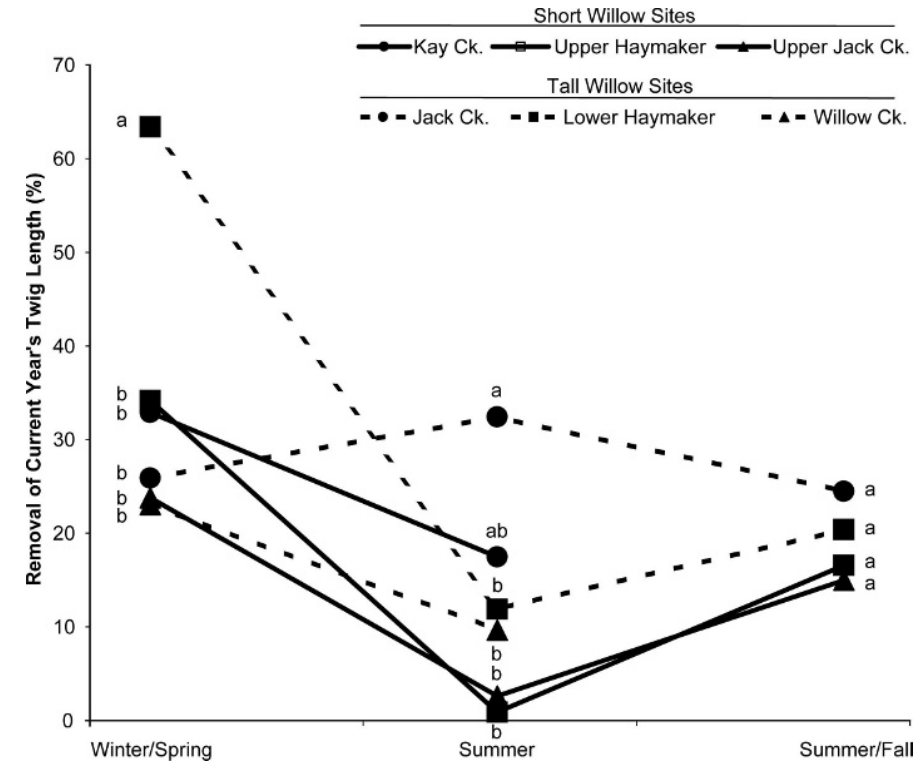

Figure 1. Willow utilization (\% removal of available current year's twig length, means for Season $\times$ Site(Height Category), $P=0.0009, n=4$ ) from three short willow sites (solid lines) and three tall willow sites (dashed lines) on the Greybull allotment. Means in a season with the same letter are not different (protected least significant difference, $\alpha=0.05)$.

\section{RESULTS}

\section{Cattle Utilization of Willow During the Study}

No cattle were present on the Greybull allotment at any time during this study. Therefore, all willow utilization reported for this allotment is a result of wildlife herbivory. Cattle used three of six sites on the Paintrock allotment during this study, and it was assumed that all willow utilization measured while cattle were in a particular study site was a result of cattle browsing even though wildlife may have also browsed willows. Cattle were not on the Paintrock allotment before the summer period, so all winter/spring utilization was attributed to wildlife. Summer willow utilization at North Fork was $11 \pm 3 \%$ (mean \pm SE, $n=4)$ over the $2 \mathrm{~d}$ that cattle were present $(0.33$ animal unit months $\left.[\mathrm{AUM}] \cdot \mathrm{ha}^{-1}\right)$. Summer/fall willow utilization there was $24 \pm 3 \%$ for the $9 \mathrm{~d}$ when cattle were present $\left(1.46 \mathrm{AUM} \cdot \mathrm{ha}^{-1}\right)$. Cattle were in North High Park only during the summer/fall period (18 d, $\left.0.96 \mathrm{AUM} \cdot \mathrm{ha}^{-1}\right)$, and willow utilization was $28 \pm 11 \%$ while cattle were present. Negligible summer willow utilization was detected in Willow Swamp, but during the summer/fall period, $34 \pm 2 \%$ of available current year's twig length was removed while cattle were present $(9 \mathrm{~d}$, 1.46 AUM $\left.\cdot \mathrm{ha}^{-1}\right)$. Cattle utilization of willow reported above is not included in any of the estimates of wildlife utilization of willow that follow.

\section{Total Annual Willow Utilization by Wildlife Compared to National Park Estimates}

The estimate of total annual willow utilization for national parks is $30-35 \%$ of current year's willow growth (Singer et al. 1998b; Zeigenfuss et al. 2002). Total annual willow utilization on the Greybull allotment was $53 \pm 9 \%$ (mean \pm SE, $n=6$ sites), which was not greater than $35 \%(P=0.0864)$, but was

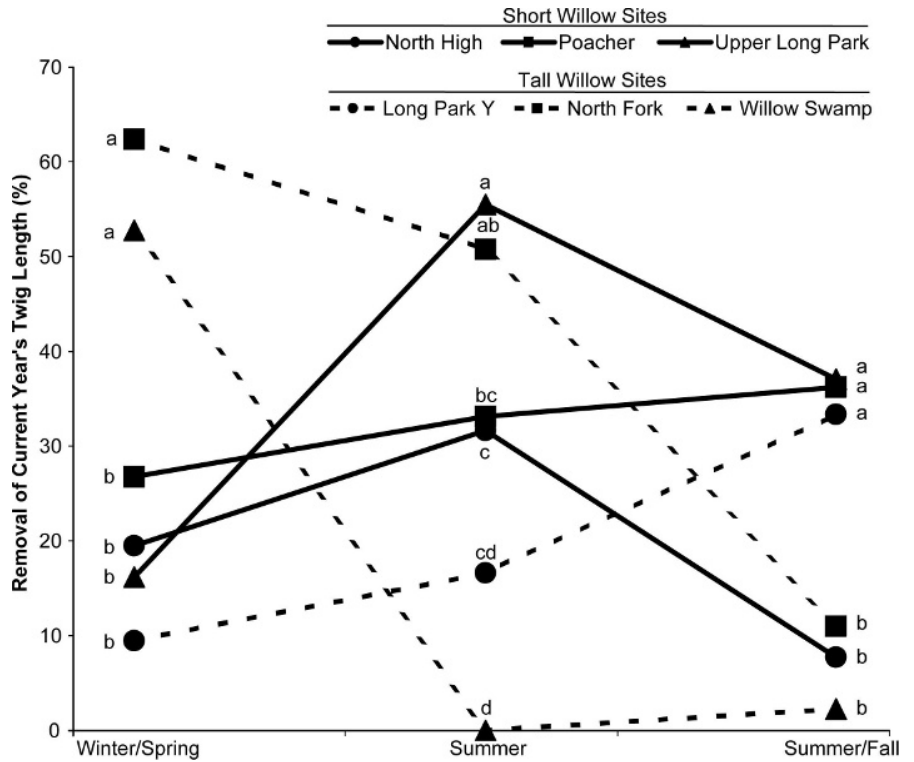

Figure 2. Willow utilization (\% removal of available current year's twig length, means for Season $\times$ Site(Height Category), $P<0.0001, n=4$ ) from three short willow sites (solid lines) and three tall willow sites (dashed lines) on the Paintrock allotment. Means in a season with the same letter are not different (protected least significant difference, $\alpha=0.05)$.

greater than $30 \%(P=0.0421)$. Total annual willow utilization on the Paintrock allotment was $58+7 \%($ mean + SE, $n=6$ sites $)$, which was greater than $35 \%(P=0.0203)$.

\section{Seasonal Utilization of Tall and Short Willow Sites by Wildlife}

On both allotments, the interaction between season and site within height category was significant $(P=0.0009$ Greybull; $P<0.0001$ Paintrock), so generalizations could not be made for height categories. Seasonal willow utilization patterns for the Greybull and Paintrock allotments are presented in Figures 1 and 2, respectively.

On the Greybull allotment (Fig. 1), winter/spring willow utilization was greatest at one of the tall willow sites (Lower Haymaker). Willow utilization in this period was lower for the other two tall willow sites, which were not different from the three short willow sites. In the summer, a different tall willow site (Jack Creek) had the greatest willow utilization, which was significantly different from the other two tall willow sites and two of the three short willow sites. In the summer/fall period, there were no differences among sites.

On the Paintrock allotment (Fig. 2), winter/spring willow utilization was greater at two tall willow sites (North Fork and Willow Swamp) than the other four sites. Interestingly, the third tall willow site (Long Park Y) had the lowest utilization value for this period, although not statistically different from the three short willow sites. In the summer period, there were significant differences in willow utilization between sites, but no clear patterns driven by height category. Summer willow utilization remained high at one of the tall willow sites (North Fork), but dropped to zero at another (Willow Swamp). The third tall willow site (Long Park Y) had summer willow utilization similar to two of the three short willow sites (North 
Table 2. Total annual willow utilization (percentage removal of current year's willow twig length) for three short willow sites and three tall willow sites on the Greybull and Paintrock allotments in northern Wyoming. For each allotment, means with the same letter are not different (protected least significant difference, $\alpha=0.05$ ).

\begin{tabular}{llcc}
\hline \multicolumn{1}{c}{ Site } & $\begin{array}{c}\text { Height } \\
\text { category }\end{array}$ & $\begin{array}{c}\text { Total annual willow } \\
\text { utilization (\%) }\end{array}$ & $\begin{array}{c}\text { Pooled SE, } \\
n=4\end{array}$ \\
\hline $\begin{array}{lll}\text { Greybull allotment } \\
\text { Lower Haymaker }\end{array}$ & Tall & $87 \mathrm{a}$ & 9.9 \\
Jack Creek & Tall & $70 \mathrm{ab}$ & 9.9 \\
Upper Haymaker & Short & $50 \mathrm{bc}$ & 9.9 \\
Kay Creek & Short & $40 \mathrm{c}$ & 9.9 \\
Upper Jack Creek & Short & $39 \mathrm{c}$ & 9.9 \\
Willow Creek & Tall & $34 \mathrm{c}$ & 9.9 \\
Paintrock allotment & & & \\
North Fork & Tall & $81 \mathrm{a}$ & 6.8 \\
Upper Long Park & Short & $67 \mathrm{ab}$ & 6.8 \\
Poacher & Short & $65 \mathrm{ab}$ & 6.8 \\
Willow Swamp & Tall & $52 \mathrm{bc}$ & 6.8 \\
Long Park Y & Tall & $44 \mathrm{c}$ & 6.8 \\
North High & Short & $36 \mathrm{c}$ & 6.8 \\
\hline
\end{tabular}

High and Poacher). One short willow site (Upper Long Park) was among the group with the greatest summer willow utilization. In the summer/fall period, sites separated into two groups consisting of three sites each. The group with the greatest summer/fall willow utilization included two short willow sites (Upper Long Park and Poacher) and one tall willow site (Long Park Y). The other group included two tall willow sites (North Fork and Willow Swamp) and one short willow site (North High) and had significantly lower summer/ fall willow utilization.

\section{Total Annual Utilization of Tall and Short Willow Sites by Wildlife}

Total annual willow utilization by wildlife on the Greybull allotment varied by height category $(P=0.0216)$, and by site within height category $(P=0.0165)$. Averaged across sites within height categories, total annual willow utilization was higher at tall willow sites $(63 \%)$ than short willow sites $(43 \%)$ $(P=0.0216)$. However, there were differences among sites within height categories (Table 2). Two tall willow sites on the Greybull allotment (Lower Haymaker and Jack Creek) were among those with the greatest total annual willow utilization, while the other tall willow site (Willow Creek) was among those with the least. Total annual willow utilization at short willow sites tended to be lower, but one short willow site (Upper Haymaker) was also among the sites with the greatest total annual willow utilization.

On the Paintrock allotment, there was no difference in total annual willow utilization by wildlife between short $(56 \%)$ and tall willow communities $(59 \% ; P=0.6347)$, but site within height category was a significant term in the model $(P=0.0011$; Table 2). One tall willow site (North Fork) and two short willow sites (Upper Long Park and Poacher) were among those with greater total annual willow utilization by wildlife. The other tall willow sites (Willow Swamp and Long Park Y) and the remaining short willow site (North High) were among those with lower utilization.

\section{DISCUSSION}

Management and conservation of riparian willow communities should consider herbivory by all large ungulates using the area. This study focused on quantifying wildlife utilization of willow, which required quantification of willow herbivory by cattle at three of the six Paintrock sites. Willow utilization measured while cattle were present for $2-18 \mathrm{~d}$ confirms that it is important to consider livestock use of willow, as is often done. However, willow herbivory by wild ungulates in areas other than National Parks is sometimes overlooked. Our results consistently suggest that willow herbivory by wildlife can be a significant management consideration in areas other than national parks and that generalizations based on willow height can be problematic. Based on the two allotments we studied, it was much more important and informative to consider willow utilization on a site by site basis. Most studies that estimated livestock willow utilization (except Smith et al. 1992) rely on one determination per year, which represents all willow use that occurred over an entire growing season by all animals present (Roath and Krueger 1982; Kauffman et al. 1983; Myers 1989). Contrary to expectations, cattle presence on the Paintrock allotment during summer did not contribute to the high summer willow utilization we detected. For areas other than national parks, there seems to be a tendency to monitor only willow utilization subsequent to livestock presence in a given year, and an inclination to skip monitoring in years when no livestock use occurred. However, monitoring willow utilization when livestock are absent provides opportunities to more clearly quantify willow use by wild herbivores, so monitoring is encouraged regardless of livestock presence or absence.

We rejected our hypothesis that total annual willow utilization on the Paintrock and Greybull allotments would not differ from published estimates of $30-35 \%$ for YNP and RMNP. Estimates for the Greybull allotment exceeded the lower end of the published range, but not the upper. On the other hand, total annual willow utilization on the Paintrock allotment exceeded the upper end of the published range for YNP and RMNP. Although it is interesting to consider our estimates of willow utilization relative to what others have reported, it is important to realize that a variety of approaches are used to estimate willow utilization. Singer et al. (1998b) reported that willow utilization in YNP and RMNP was around $30 \%$ of current annual growth based on measurements of $30-75 \%$ willow leader use and $35-50 \%$ removal of twig length. Zeigenfuss et al. (2002) stated that $33 \%$ utilization of current year's willow growth by elk was common in RMNP. Some estimates of utilization rely on post-browsing twig diameter measurements, which may underestimate willow utilization at higher intensities (Bilyeu et al. 2007), and this may help explain the lower estimates reported for national parks.

Interestingly, Zeigenfuss et al. (1999) estimated that approximately $85 \%$ of willow leaders were browsed in RMNP from 
1968 to 1993 , and Baker et al. (2005) reported that $86-92 \%$ of twigs were browsed annually by elk $2 \mathrm{yr}$ following simulated beaver cutting in RMNP. Brookshire et al. (2002) estimated utilization at a meadow in northeast Oregon and reported that $90-100 \%$ of willow plants were browsed, regardless of whether only wild ungulates or wild ungulates and domestic sheep had access to the area, but those authors did not estimate the percentage of current annual growth removed.

We also rejected our macro-hypothesis that seasonal patterns of willow utilization would differ between short and tall willow sites on both allotments because of differences between sites within height categories. On the Greybull allotment, the subhypothesis that winter/spring willow utilization would be higher at tall willow sites than short willow sites was true for only one of three tall willow sites. On the Paintrock, this held for two of three tall willow sites. Further, we hypothesized that summer and summer/fall willow utilization would not differ between tall willow sites and short willow sites. There were significant differences between individual tall willow sites and individual short willow sites in summer and summer/fall periods.

For both allotments we rejected the hypothesis that total annual willow utilization would be greater for short willow sites compared to tall willow sites. On the Greybull, it appeared that the opposite might be true, and on the Paintrock, there was no difference between tall and short willow sites. More importantly, total annual willow utilization depended on site within height categories. An example of how willow height has been used to draw conclusions about browsing pressure is found in Singer et al. (1994). That study defined heightsuppressed willows as those less than $0.8 \mathrm{~m}$ tall, which is the expected potential height for Wolf's willow in the absence of browsing (Brunsfeld and Johnson 1985; Dorn 1992). Wolf's willow appears to be the only willow present in one of the two "height-suppressed" communities described in that study. Similar mistakes have been made involving the two varieties of planeleaf willow (Salix planifolia Pursh). Salix planifolia var. planifolia Pursh is a medium sized shrub, commonly 2-4 m tall, while Salix planifolia Pursh var. monica (Bebb) Schneider is a low shrub, mostly 0.4-1.0 m tall (Brunsfeld and Johnson 1985; Dorn 1992). It is commonly assumed that willow communities dominated by $S$. planifolia var. monica have a "short appearance" because of heavy ungulate browsing, but this is not accurate.

Differences among sites are likely driven by differences in numbers, kinds, and seasonal habits of wild ungulates in combination with site characteristics (e.g., elevation, willow species composition, position in the landscape, proximity to travel corridors, water and mineral sources, and hiding cover). The highest seasonal willow utilization estimated on the Greybull allotment occurred during the winter/spring period at Lower Haymaker. We commonly observed moose at this site and noted abundant moose droppings. Although elk and deer also use the Greybull allotment, we suspect that a majority of the willow utilization observed on this site was a result of moose browsing. Willow is a major component of moose diets in summer and winter (Gaffney 1941; Harry 1957; Dorn 1970). Moose were observed using this study site in summer, and local USFS, Wyoming Game and Fish personnel, and ranchers believe this location is important moose winter range as well. Drummond's willow (Salix drummondiana Barratt ex
Hook.) is a primary source of winter browse for moose (Wilson 1971; Wolfe et al. 1983), and in Montana, communities dominated by this species often receive moderate to heavy ungulate use, especially in winter (Hansen et al. 1988). Drummond's willow is the dominant species at both the Lower Haymaker and Jack Creek sites. Moose were commonly observed at the Jack Creek site and were likely responsible for most of the utilization measured there.

The Upper Jack Creek site is immediately upstream from the Jack Creek transects, and willow utilization there was low during the winter/spring and summer/fall periods and undetectable during summer. Wolf's willow was the only shrub at Upper Jack Creek. This low-growing shrub would not likely receive much winter use at high elevations by wildlife because it is easily covered by snow, but it may be used in other seasons (Youngblood et al. 1985; Hansen et al. 1988). Girard et al. (1997) suggested Wolf's willow has low palatability, which could help explain the low use we measured at this site. Because Upper Jack Creek is a high elevation site and subject to heavy snowpack, we believe that the low winter/spring use we observed occurred in fall before snow cover or in the spring after snowmelt.

Planeleaf willow was a major component of the other three sites on this allotment. Youngblood et al. (1985), Hansen et al. (1988), and Padgett et al. (1989) suggested that wildlife make moderate use of planeleaf willow communities. Although this willow is considered key browse for moose (Windell et al. 1986), we believe that these three study sites were used primarily by elk. During the 7-yr period including and before this study, we observed mostly elk, and not moose, using these sites during early spring and late fall.

Willow is considered valuable for elk and may receive moderate to heavy use (Gaffney 1941; Kufeld 1973; Nelson and Leege 1982). Gaffney (1941) suggested that elk graze primarily on herbaceous plants when available but browse willow in winter or when other food is not available. Utilization patterns of our planeleaf willow sites (Upper Haymaker, Kay Creek, and Willow Creek) followed Gaffney's (1941) observations with higher use in winter/spring than summer. Kay Creek and Upper Haymaker support S. planifolia var. monica, which, like Wolf's willow, is low growing and prone to being covered by snow. Wildlife use of willow at these two sites likely occurred in spring, after snowmelt, or in fall before plants were covered.

Moose were not abundant on the Paintrock allotment, so a majority of the wildlife utilization measured there was likely elk herbivory. Collared elk were located throughout the Paintrock allotment between 15 June and 17 August of 1994 and 1995 (Sawyer 1997). Summer resident elk were observed in Upper Long Park, and two other herds of elk moved through the area on their way to and from summer range. Further, it appears that cow elk preferred riparian habitats in our study area during summer (Sawyer 1997).

The North Fork and Willow Swamp sites are used by elk transitioning between summer and winter range. These sites were dominated by Eastwood's and Drummond's willow along with S. planifolia var. planifolia. All three are palatable to, and commonly used by, wildlife (Windell et al. 1986; Hansen et al. 1988; Padgett et al. 1989; Girard et al. 1997). Also, most shrubs at these sites were 1-2 $\mathrm{m}$ tall and accessible when 
substantial amounts of snow accumulated. Willow utilization at these two sites and Upper Long Park, in the winter/spring and summer, was dominated by wildlife. Wildlife utilization patterns on the Greybull allotment were different, in some cases, than those observed on the Paintrock allotment. High utilization occurred mostly in winter/spring on the Greybull. In contrast, summer utilization exceeded $50 \%$ at two sites on the Paintrock. Summer use was generally lower than the other two seasons on the Greybull. Differences in utilization patterns observed on the two allotments suggested that much of the Paintrock is used by animals transitioning between summer and winter range and that some areas on the Greybull are winter ranges. The other obvious difference between the two allotments was the presence of moose on the Greybull allotment, and the scarcity of moose on the Paintrock allotment during this study.

\section{IMPLICATIONS}

The degree of willow utilization by wildlife observed in this study equaled or exceeded that reported in national parks, where significant concern has been expressed about riparian willow community conditions. Zeigenfuss et al. (2002) concluded that "reducing elk numbers and/or reducing elk concentrations will result in increases in willow productivity and heights of willow" in national parks, and suggested that fencing some willow communities in parks may be necessary. It is clear that wildlife impact on willow can be significant in areas other than national parks, and domestic livestock can represent an additional impact on willow communities. Those interested in the management and ecology of riparian systems should attempt to recognize multiple sources of willow herbivory and resist temptations to attribute all willow utilization to one group of herbivores. Monitoring willow utilization only subsequent to livestock presence is strongly discouraged. Rather, monitoring willow utilization during periods of livestock absence should be used to estimate wild ungulate use of willow. Further, it is strongly recommended that an attempt be made to estimate willow utilization separately for livestock and wild ungulates where both groups of animals occur.

Although it is tempting to make generalizations across a variety of willow sites, it appears that such generalizations are problematic. We addressed one common generalization specifically (willow height) and were unable to make generalizations about seasonal or total annual willow utilization. Generalizations based solely on elevation or species composition may be problematic as well. The most effective and likely the most appropriate conservation and management decisions will be based on site-specific information as opposed to generalizations.

\section{ACKNOWLEDGMENTS}

Special thanks to Fred Lindzey, Tom Wesche, and Bill Laycock for their valuable input in the planning stages of this study. Numerous individuals from the Pitchfork and Hyatt ranches and the Forest service made this research possible and enjoyable, especially Jack and Lili Turnell, Joe and Tracy Thomas, Louis and Rebecca Abar, Ray and Ruth Mills, Paula and
Bill Grigsby, Wes and Margaret Hyatt, Lon and Jana Timberman, Jeff and Jean Petty, Dustin Cushman, Joe Hicks, and Dave Morris. We also appreciate the insightful reviews provided by Joe Brummer, anonymous reviewers, the editor, and the associate editor.

\section{LITERATURE CITED}

Baker, B. W., H. C. Ducharme, D. C. S. Mitchell, T. R. Stanley, and H. R. Peinetti. 2005. Interaction of beaver and elk herbivory reduces standing crop of willow. Ecological Applications 15:110-118.

Bighorn National Forest. 1995. Bighorn national forest vegetation grazing standards, July 12, 1995. Sheridan, WY, USA: Bighorn National Forest. 13 p.

Bighorn National Forest. 2007. Bighorn national forest vegetation grazing guidelines. 2007 edition. Sheridan, WY, USA: Bighorn National Forest. 12 p.

Bilyeu, D. M., D. J. Cooper, and N. T. HobBs. 2007. Assessing impacts of large herbivores on shrubs: tests of scaling factors for utilization rates from shootlevel measurements. Journal of Applied Ecology 44:168-175.

Brookshire, E. N. J., J. B. Kauffman, D. Lytuen, and N. Otting. 2002. Cumulative effects of wild ungulate and livestock herbivory on riparian willows. Oecologia 132:559-566.

Brunsfeld, S. J., AND F. D. Johnson. 1985. Field guide to the willows of east-central Idaho. Moscow, ID, USA: Idaho Forest, Wildlife and Range Experiment Station, Bulletin Number 39. 95 p.

Burton, T., N. Bare, G. Ketcheson, H. Hudak, W. Little, W. Grow, T. M. Collins, A. H. Winward, D. Duff, and H. Forsgren. 1992. Integrated riparian evaluation guide. Ogden, UT, USA: USDA Forest Service, Intermountain Region. $54 \mathrm{p}$.

Chadde, S. W., and C. E. Kay. 1991. Tall willow communities on Yellowstone's Northern Range: a test of the "Natural-Regulation" paradigm. In: R. B. Keiter and M. S. Boyce [EDS.]. The greater Yellowstone ecosystem: redefining America's wilderness heritage. New Haven, CT, USA: Yale University Press. p. 231-262.

Conroy, S. D., And T. J. Svescar. 1991. Willow planting success as influenced by site factors and cattle grazing in northeastern California. Journal of Range Management 44:59-63.

Dahlem, E. A. 1978. The Mahogany Creek watershed-with and without grazing. In: 0. B. Cope [ED.]. Forum—grazing and riparian/stream ecosystems. Denver, CO, USA: Trout Unlimited, Inc. p. 31-34.

Dorn, R. D. 1970. Moose and cattle food habits in southwest Montana. Journal of Wildlife Management 34:559-564.

Dorn, R. D. 1992. Vascular plants of Wyoming. Cheyenne, WY, USA: Mountain West Publishing. $340 \mathrm{p}$.

DunRUD, C. R. 1962. Volcanic rocks of the Jack Creek area, southeastern Absaroka range Park County, Wyoming [thesis]. Laramie, WY, USA: University of Wyoming. $92 \mathrm{p}$.

Engeman, R. M., D. E. Palmquist, and L. L. McDonald. 1986. The use of repeated measurement designs in field studies. In: C. D. Bonham, S. S. Coleman, C. E. Lewis, and G. W. Tanner [EDS.]. Proceedings of the Statistical Analysis and Modeling of Grazing Systems Symposium; 10-14 February 1986; Kissimmee, FL, USA. Denver, CO, USA: Society for Range Management. p. 59-66.

GAFNNEY, W. S. 1941. The effects of winter elk browsing, South Fork of the Flathead River, Montana. Journal of Wildlife Management 5:427-453.

Girard, M., D. L. Wheeler, and S. B. Mills. 1997. Classification of riparian communities on the Bighorn National Forest. Denver, CO, USA: US Department of Agriculture Forest Service R2-RR-97-02. $308 \mathrm{p}$.

GiRDEN, E. R. 1992. ANOVA repeated measures. Newbury Park, CA, USA: Sage Publications. $77 \mathrm{p}$.

Green, D. M., and J. B. Kauffman. 1995. Succession and livestock grazing in a northeastern Oregon riparian ecosystem. Journal of Range Management 48:307-313.

Gunderson, D. R. 1968. Floodplain use related to stream morphology and fish populations. Journal of Wildlife Management 32:507-514.

Hansen, P. L., S. W. Chadde, and R. D. Pfister. 1988. Riparian dominance types of Montana. Missoula, MT, USA: School of Forestry, University of Montana, 
Miscellaneous Publication no. 49, Montana Forest and Conservation Experiment Station. $411 \mathrm{p}$.

HarRy, G. B. 1957. Winter food habits of moose in Jackson Hole, Wyoming. Journal of Wildlife Management 21:53-57.

Heroy, W. B. 1941. Geology of the Shell Canyon area, Bighorn Mountains, Wyoming [dissertation]. Princeton, NJ, USA: Princeton University. $107 \mathrm{p}$.

Holland, K. A., W. C. Leininger, and M. J. Trlica. 2005. Grazing history affects willow communities in a montane riparian ecosystem. Journal of Range Management 58:148-154.

Kauffman, J. B., and W. C. Krueger. 1984. Livestock impacts on riparian ecosystems and streamside management implications-a review. Journal of Range Management 37:430-438.

Kauffman, J. B., W. C. Krueger, and M. Vavra. 1983. Effects of late season cattle grazing on riparian plant communities. Journal of Range Management 36:685-691.

KAY, C. E. 1997. Viewpoint: ungulate herbivory, willows, and political ecology in Yellowstone. Journal of Range Management 50:139-145.

KNopf, F. L. 1985. Wildlife considerations in seasonal grazing of riparian zones. In: J. H. Smits [ED.]. Proceedings of the Management of Riparian Areas conference; 23 September 1985; Denver, CO, USA. Washington, DC, USA: Public Lands Council. p. 5-12.

KovalchiK, B. L., AND W. Elmore. 1992. Effects of cattle grazing systems on willowdominated plant associations in central Oregon. In: W. P. Clary, E. D. McArthur, D. Bedunah, and C. L. Wambolt [EDS.]. Proceedings of the Symposium on Ecology and Management of Riparian Shrub Communities; 29-31 May 1991; Sun Valley, ID, USA. Ogden, UT, USA: US Department of Agriculture Forest Service. p. 111-119.

Kufeld, R. C. 1973. Foods eaten by the Rocky Mountain elk. Journal of Range Management 26:106-112.

MARTIN, S. C. 1978. Evaluating the impacts of cattle grazing on riparian habitats in the National Forests of Arizona and New Mexico. In: 0. B. Cope [ED.]. Forumgrazing and riparian/stream ecosystems. Denver, CO, USA: Trout Unlimited, Inc. p. 35-38.

Matney, C. A., C. S. Boyd, and T. K. Stringham. 2005. Use of felled junipers to protect streamside willows from browsing. Journal of Range Management 58:652-655.

McMılıan, J. F. 1953. Some feeding habits of moose in Yellowstone Park. Ecology 34:102-110.

Meiman, P. J. 1996. Effects of large ungulate herbivory on willow (Salix) in mountain rangelands of northern Wyoming [thesis]. Laramie, WY, USA: University of Wyoming. $119 \mathrm{p}$.

Montgomery, D. C. 1984. Design and analysis of experiments. New York, NY, USA: John Wiley \& Sons. 643 p.

MyeRS, L. H. 1987. Riparian inventory and monitoring. Riparian technical bulletin no. 1. Billings, MT, USA: US Department of the Interior Bureau of Land Management. $37 \mathrm{p}$.

Myers, L. H. 1989. Grazing and riparian management in southwestern Montana. In: R. E. Gresswell, B. A. Barton, and J. L. Kershner [EDs.]. Proceedings, Practical Approaches to Riparian Resource Management; 8-11 May 1989. Billings, MT, USA: US Bureau of Land Management. $193 \mathrm{p}$.

Nelson, J. R., and T. A. Leege. 1982. Nutritional requirements and food habits. In: J. W. Thomas and D. E. Toweill [EDS.]. Elk of North America: ecology and management. Harrisburg, PA, USA: Stackpole Books. p. 323-367.

Padgett, W. G., A. P. Youngblood, and A. H. Winward. 1989. Riparian community type classification of Utah and southeastern Idaho. Ogden, UT, USA: US Department of Agriculture Forest Service, Report R4-Ecol-89-01. $191 \mathrm{p}$.

PLATTS, W. S. 1981. Effects of sheep grazing on a riparian-stream environment. Ogden, UT, USA: US Department of Agriculture Forest Service, Research Note INT-307. 5 p.

Platts, W. S., and R. L. Nelson. 1985. Streamside and upland vegetation use by cattle. Rangelands 7:5-7.

RickaRd, W. H., AND C. E. Cushing. 1982. Recovery of streamside woody vegetation after exclusion of livestock grazing. Journal of Range Management 35:360-361.
Roath, L. R., and W. C. Krueger. 1982. Cattle grazing influence on a mountain riparian zone. Journal of Range Management 35:100-103.

SAS INSTITUTE [computer program]. 2003. SAS/STAT Version 9.1 for Windows. Cary, NC, USA: SAS Institute.

SAwYER, H. H. 1997. Evaluation of a summer elk model and sexual segregation of elk in the Bighorn Mountains, Wyoming [thesis]. Laramie, WY, USA: University of Wyoming. $68 \mathrm{p}$.

Schoenecker, K. A., F. J. Singer, L. C. Zeigenfuss, D. Binkley, and R. S. C. Menezes. 2004. Effects of elk herbivory on vegetation and nitrogen processes. Journal of Wildlife Management 68:837-849.

Schulz, T. T., AND W. C. Leininger. 1990. Differences in riparian vegetation structure between grazed areas and exclosures. Journal of Range Management 43:295-299.

Sedgewick, J. A., And F. L. Knopf. 1991. Prescribed grazing as a secondary impact in a western riparian floodplain. Journal of Range Management 44:369373.

Shaw, N. L. 1992. Recruitment and growth of pacific willow and sandbar willow seedlings in response to season and intensity of cattle grazing. In: W. P. Clary, E. D. McArthur, D. Bedunah, and C. L. Wambolt [EDS.]. Proceedings of the Symposium on Ecology and Management of Riparian Shrub Communities; 29-31 May 1991; Sun Valley, ID, USA. Ogden, UT, USA: US Department of Agriculture Forest Service. p. 130-137.

Singer, F. J., L. C. Mark, and R. C. Cates. 1994. Ungulate herbivory of willow on Yellowstone's northern winter range. Journal of Range Management 47:435-443

Singer, F. J., D. M. Swift, M. B. Coughenour, and J. D. Varley. 1998a. Thunder on the Yellowstone revisited: an assessment of management of native ungulates by natural regulation, 1968-1993. Wildlife Society Bulletin 26:375-390.

Singer, F. J., L. C. Zeigenfuss, R. G. Cates, and D. T. Barnett. 1998b. Elk, multiple factors, and persistence of willows in national parks. Wildlife Society Bulletin 26:419-428.

Sмıтн, B. H. 1980. Riparian willow management: its problems and potentials within the scope of multiple use on public lands. In: Proceedings of the 9th Wyoming Shrub Ecology Workshop; 5-8 June 1980; Lander, WY, USA. Laramie, WY, USA: University of Wyoming. p. 15-20.

Smith, M. A., J. D. Rodgers, J. L. Dodd, ANd Q. D. Skinner. 1992. Declining forage availability effects on utilization and community selection by cattle. Journal of Range Management 45:391-395.

Szaro, R. C., AND C. P. PASE. 1983. Short-term changes in a cottonwood-ash-willow association on a grazed and an ungrazed portion of Little Ash Creek in central Arizona. Journal of Range Management 36:382-384.

Thorne, M. S., P. J. Meiman, Q. D. Skinner, M. A. Smith, and J. L. Dodd. 2005. Clipping frequency affects canopy volume and biomass production in planeleaf willow (Salix planifolia var. planifolia Pursh). Rangeland Ecology and Management 58:41-50.

US Department of the Interior Bureau of Land Management. 1993. Riparian area management: process for assessing proper functioning condition. Denver, CO, USA: USDI BLM, Technical Reference 1737-9. 80 p.

US Department of the Interior Bureau of Land Management. 1994. Rangeland Reform '94. Draft environmental impact statement. Washington, DC, USA: USDI BLM. $492 \mathrm{p}$.

Van Velson, R. 1978. Effects of livestock grazing upon rainbow trout in Otter Creek, Nebraska. In: O. B. Cope [ED.]. Forum-grazing and riparian/stream ecosystems. Denver, C0, USA: Trout Unlimited, Inc. p. 53-55.

WILson, D. E. 1971. Carrying capacity of the key browse species for moose on the north slopes of the Uinta Mountains, Utah. Salt Lake City, UT, USA: Utah Division of Wildlife Resources Publication No. 71-9. 57 p.

Windell, J. T., B. E. Willard, D. J. Cooper, S. Q. Foster, C. F. Knud-Hansen, L. P. RinK, AND G. N. KILADIS. 1986. An ecological characterization of Rocky Mountain montane and subalpine wetlands. Washington, DC, USA: US Department of the Interior Fish and Wildlife Service, Biological Report 86(11). $323 p$.

Winward, A. H. 1985. Vegetation characteristics of riparian areas. In: J. H. Smits [ED.]. Proceedings, Management of Riparian Areas; 23 September 
1985; Denver, C0, USA. Washington, DC, USA: Public Lands Council. p. 5-12.

Wolfe, M. L., W. H. Babcock, and R. M. WelCh. 1983. Effects of simulated moose browsing on Drummond's willow. Alces 64:14-35.

Wyman, S., D. Balley, M. Borman, S. Cote, J. Eisner, W. Elmore, B. Leinard, S. Leonard, F. Reed, S. Swanson, L. Vanriper, T. Westfall, R. Wiley, and A. Winward. 2006. Riparian area management: grazing management processes and strategies for riparian-wetland areas. Denver, CO, USA: US Department of the Interior, Bureau of Land Management, National Science and Technology Center, Technical Reference 1737-20. BLM/ST/ST-06/002+1737. 105 p.
Youngblood, A. P., W. G. Padgett, and A. H. Winward. 1985. Riparian community type classification of eastern Idaho-western Wyoming. Ogden, UT, USA: US Department of Agriculture Forest Service, Report R4-Ecol-85-01. 78 p.

Zeigenfuss, L. C., F. J. Singer, and D. Bowden. 1999. Vegetation responses to natural regulation of elk in Rocky Mountain National Park. Denver, CO, USA: US Government Printing Office, Biological Science Report USGS/BRD/BSR1999-0003. 23 p.

Zeigenfuss, L. C., F. J. Singer, S. A. Williams, and T. L. Johnson. 2002. Influences of herbivory and water on willow in elk winter range. Journal of Wildlife Management 66:788-795. 